\title{
Bibliography of Finnish Population Research $1981-1982$
}

The bibliography covers the literature on population research published in Finland during 1981-1982. Included are independent publications, articles in periodicals and statistics published in Finland as well as publications on Finnish population questions published abroad. In general the bibliography excludes nonscientific articles in newspapers and weeklies as well as unpublished reports and academic theses. Also not included are studies presented at proceedings of conferences held in Finland if they were written abroad and treated subjects outside Finland. Coverage is less complete in peripheral fields.

In principle the main divisions appearing in the Population Index have been used with added subdivisions better suiting Finnish circumstances. Studies covering several fields of demography, which should rightly be listed in two or more divisions are included in only one division, i.e. in the division representing the primary field, on which the report is centered.

Lists of literature on population research have been published in Yearbooks II-IV of the Finnish Population and Family Welfare Federation and since 1960 in the Yearbook of Population Research, at first every fourth year and now every second year.

\section{A. GENERAL POPULATION STUDIES AND THEORY}

Lallukka, Seppo. Neuvostoliiton väestörakenteen kehityspiirteitä viimeisten väestönlaskentojen valossa tarkasteltuna. (Developmental features of the population structure of the USSR in view of the latest population censuses.) Neuvostoliittoinstituutti, Tiedonantoja ja katsauksia 1981: 2, $20 \mathrm{pp}$.

Lallukka, Seppo. Suomalais-ugrilaiset kansat Neuvostoliiton uusimpien väestönlaskentojen valossa. (Finno-ugric peoples in the post-war Soviet censuses). Neuvostoliittoinstituutti, (Institute for Cultural Relations between Finland and the U.S.S.R.) Julkaisusarja A, 11, Helsinki 1982, 131 pp. (English summary).
Mustalaisasiainneuvottelukunta. Mustalaiset vähemmistönä suomalaisessa yhteiskunnassa. (Gypsies as a minority in Finnish society). Helsinki 1981, 167 pp.

Vaasan läänin seutukaavaliitto. Muutto takaisin kotiin. Mitä ongelmia kotiinpalaava Ruotsin siirtolainen kohtaa? (Moving back home. What are the problems an emigrant to Sweden experiences when he returns to Finland?) Sarja D: 4, Vaasa 1981, 14 pp. + pictures + appendices.

Vanamo, Jorma. Suomen ja Ruotsin suhteet. Siirtolaisongelma taitekohdassa? (Relations between Finland and Sweden. A turning point in the migration problem?) Kanava 1981: 7, 390$395 \mathrm{pp}$.

\section{B. REGIONAL POPULATION STUDIES}

Asp, Erkki \& Vakkamaa, Juhani \& Aho, Harri. The Skolt Lapps. On their way of life and present-day living conditions. Sociological Studies Series A, 6, Department of Sociology and Political Research, University of Turku, Turku 1982, 62 pp.

Kanta-Hämeen seutukaavaliitto. Väestönkehitys osa-alueilla Kanta-Hämeessä vuosina 19711980. (Population development in subareas of Kanta-Häme in 1971-1980.) Hämeenlinna $1982,10 \mathrm{pp}$. + appendices.

Kanta-Hämeen seutukaavaliitto. Väestönmuutos Kanta-Hämeen muiden kuntien (ei kaupunkien) osa-alueilla v. 1980. (Population change in subareas of the other municipalities (not including towns) in Kanta-Häme in 1980). Hämeenlinna 1982, 18 pp. + tables.

Kirkinen, Heikki. Problemes du developpement en Finlande et en France: colloque francofinlandais à Savonlinna, $17-18$ aout 1981 . University of Joensuu, Karjalan tutkimuslaitoksen julkaisuja no. 46, Joensuu 1981, 178 pp.

Kuusilinna, Pirjo. Tampereen väestönkehitys 1950-80. Tilastollisia tiedonantoja Tampereelta 1982: 2. (Population development in Tampere during 1950-80. Statistical reports on Tampere.) $63-79 \mathrm{pp}$. 
Melkas, Jussi. Kainuun ja Kemi-Tornion talousalueiden väestö- ja työvoimakehityksen kuvaus. Kostamus-Tornio-projekti. (A report on population and labor force development in the Kainuu and the Kemi-Tornio economic region. The Kostamus-Tornio-project). Pohjois-Suomen tutkimuslaitoksen julkaisu C 30 , University of Oulu, Oulu 1981, 194 pp.

Nurmela, Juha. Vanha Porvoo 80-tutkimus: vanhan Porvoon väestön ja asuntokannan muutokset 1970-luvun lopulla. (Old Porvoo 80study: changes in the population and housing of old Porvoo at the end of the 1970's). Department of Sociology, University of Helsinki, Working papers 20, Helsinki 1981, 79 pp.

\section{SPATIAL DISTRIBUTION}

Seutusuunnittelun keskusliitto. Suomen aluerakenne 1990, yhteenveto, Seutukaavaliittojen nkokonaissuunnitelmien 1980" mukaan. (The regional structure of Finland in 1990, summary according to the $» 1980$ total plans» of the Regional Planning Authorities). Seutusuunnittelu 4: 1981,95 pp.

\section{TRENDS IN POPULATION SIZE}

Fougstedt, Gunnar. Trender för finlandsvensk befolkningsutveckling. Vetenskap och företagsledning. (Trends in population development of Swedish-speaking Finns, Essays in economics and management in honor of Lars Wahlbeck) Ekonomi och samhälle, Publications of the Swedish School of Economics and Business Administration No. 31, Helsingfors 1982, 107$126 \mathrm{pp}$.

Lindgren, Jarl \& Ritamies, Marketta. Suomen väestönkehitys 1970-luvulla. Väestöntutkimuslaitos - The Population Research Institute Helsinki, Väestőntutkimuslaitoksen julkaisusarja D, no. 9/1982, Vammala 1982, 24.

Lindgren, Jarl \& Ritamies, Marketta. Population Development in Finland in the 1970s. Yearbook of Population Research in Finland, XIX. The Population Research Institute, Vammala 1981, 11-27 pp.

Rasmussen, Johnny. Folkemengders bevegelse 1945-1977/78: Danmark, Finland, Norge og Sverige kommentarutgave. (Population movement during 1945-1977/78: Denmark, Finland, Norway and Sweden: commentary). Rapport,
Norsk samfunnsvitenskapelig datatjeneste, Bergen 1981, 137 pp.

Valkonen, Tapani. Väki lisääntyy vähemmän. (World population growth slowing down). Tiede 2000 - Science 2000, no. 5: 1982, 39-42 pp. (English summary).

\section{E. MORTALITY}

Boström, Harry \& Lungstedt, Nils. Medical aspects of mortality statistics. Symposium, September 23-25. 1980. Skandia International Symposia, Stockholm 1981, 387 pp.

Dödlighet och dödsorsaker i olika yrkesgrupper och socio-ekonomiska grupper i Finland, Danmark och Norge. (Mortality and causes of death in different occupations and socio-economic groups in Finland, Denmark and Norway). Statens offentliga utredningar 1981: 2, 266$281 \mathrm{pp}$.

Kettunen, Paavo. Kuolemaan johtaneet tapaturmat maataloudessa v. 1980. (Fatal accidents in agriculture in 1980). Työterveyslaitos, Katsauksia 50, Helsinki 1982, 23 pp. + 4 appendices.

Kuolemansyyt 1977 (Causes of death in Finland 1977) Official Statistics of Finland VI B: 133, Helsinki 1981, 121 pp.

Kuolemansyyt 1978 (Causes of death in Finland 1978) Official Statistics of Finland VI B: 134, Helsinki 1981, 141 pp.

Martelin, Tuija \& Valkonen, Tapani. Tupakointimuutokset ja keski-ikäisten miesten kuolleisuus Suomessa vuosina 1951-1975 sekä laskelmia vuoteen 2000. (Changes in smoking habits and mortality among middle-aged men in Finland: development in 1951-75 and projections to the year 2000). Department of Sociology, University of Helsinki, Working papers N:o 19 1981, Helsinki 1981, 82 pp. (English summary)

Notkola, Veijo. Regional Differences in Mortality from Diseases of the Circulatory System in Finland in the 1930's: a preliminary report. Prepared for the sixth Scandinavian demographic symposium, in Kungälv, Sweden, June 16-19 1982, Department of sociology, University of Helsinki, Working papers N:o 27, 1982, 7 pp.

Valkonen, Tapani \& Niemi, Marja-Liisa. The development of cardiovascular mortality in Finland from 1951 to 1978 . Yearbook of Population Research in Finland. XX, The Population Research Institute, Vammala 1982, 32-44 pp. 
Valkonen, Tapani \& Sauli, Hannele. Koulutusaste ja kuolleisuus verenkiertoelinten tauteihin. Tutkimus ja kansanterveys 1980, Symposiumiraportti Osa II: Sydän- ja verisuonitautitutkimus. (The degree of education and cardiovascular mortality rates. Symposium on public health research 1980. Part II: Cardiovascular research and nutritional research). Suomen Akatemian julkaisuja 4/1981, (The Academy of Finland) Helsinki 1981, 37-53 pp. (English summary)

Valkonen, Tapani. Kuolleisuuden kehitys 1970-luvulla. (Development of mortality in the 1970's). Sosiaalinen Aikakauskirja 1/1982, Helsinki 1982, 17-22 pp.

Valkonen, Tapani. Mortality Trends and Projections in four Nordic Countries. Prepared for the sixth Scandinavian demographic symposium, in Kungälv, Sweden, June 16-19 1982, Working papers N:o 26, 1982, Department of Sociology, University of Helsinki, $16 \mathrm{pp}$.

Valkonen, Tapani. Psychosocial Stress and Sociodemographic Differentials in Mortality from Ischaemic Heart Disease in Finland. Department of Sociology, University of Helsinki, Acta Med Scand (Suppl) 660: 982, Reprint N:o 121, 152-164 pp.

Valkonen, Tapani. Sociodemographic Mortality Differentials among Middle-aged Men in Finland and Problems in Accounting for them. Prepared for the Session F. 12 of the General Conference of the International Union for the Scientific Study of Population, 9-16 December 1981, Manila, Philippines, Department of Sociology, University of Helsinki, Working papers $\mathrm{N}$ :o 25,1982 , (spontaneous paper) $20 \mathrm{pp}$.

Valkonen, Tapani \& Pyörälä, Kalevi. Sydänja verisuonitautien kuolleisuuden kehityssuuntaukset ja niiden taustalla olevat tekijät. Tutkimus ja kansanterveys 1980, Symposiumiraportti Osa I: Yleisluennot. (The trends of cardiovascular mortality and factors which influence these trends. Symposium on public health research Part I: Lectures of a General Nature). Suomen Akatemian julkaisuja 3/1981, (The Academy of Finland) Helsinki 1981, 30-65 pp. (English summary)

Valkonen, Tapani \& Pyörälä, Kalevi. Sydänja verisuonitautien kuolleisuuden kehityssuuntaukset ja niiden taustalla olevat tekijät. Tutkimus ja kansanterveys 1980, Symposiumiraportti Osa II: Sydän- ja verisuonitautitutkimus. (The trends of cardiovascular mortality and factors which influence these trends. Symposium on public health research 1980. Part II: Cardiovascular research and nutritional research). Suomen Akatemian julkaisuja 4/1981, (The Academy of Finland) Helsinki 1981, 1-36 pp. (English summary)

Valkonen, Tapani \& Niemi, Marja-Liisa \& Notkola, Veijo. Verenkiertoelinten tautien aiheuttama keski-ikäisten miesten kuolleisuus ja työkyvyttömyys 1970-luvulla sekä ennustelaskelmia vuoteen 1990. (Cardiovascular mortality among middle-aged men and work disability in the 1970s with projections to the year 1990.) Department of Sociology, University of Helsinki, Working papers $18,1981,22 \mathrm{pp}$.

\section{F. FERTILITY AND NATURAL INCREASE}

Lindgrén, Susanne. Utomäktenskaplig fertilitet i Helsingfors under 1800-talets senare del. (Illegitimate fertility in later 19th century Helsinki). När samhället förändras - Kun yhteiskunta muuttuu. Societas Historica Finlandiae, Historiallinen Arkisto 76, Helsinki 1981, 301-320 pp (English summary)

Lithell, Ulla-Britt. Breast-feeding and reproduction: studies in marital fertility and infant mortality in 19th century Finland and Sweden. Acta Universitatis, Uppsala 1981, 87 pp.

Myhrman, Antero. Ei-toivotun raskauden sosiaaliset ja taloudelliset vaikutukset perheeseen ja lapseen. (Social and economic effects of the undesired pregnancy on family and child). Department of Sociology, University of Helsinki (licentiate thesis) 1981.

Peltonen, Raili. Abortti. Rikos vai oikeus. (Abortion. A crime or a right). Kanava 1: 1982, $18-20 \mathrm{pp}$.

Salo, Mikko A. Measuring the effects of social security programs on fertility levels. To be presented at the meeting of the demographic working group of Humboldt University in Berlin, GDR, May 26, 1981, Department of Social Policy, University of Tampere, Working papers 3 , 1981, 1-16 pp.

\section{G. MARRIAGE, DIVORCE AND THE FAMILY}

Aromaa, Kauko \& Cantell, Ilkka \& Jaakkola, Risto. Avoliitto. Tutkimuksia avoliiton yleisyydestä ja yleistymisestä Suomessa. (Cohabitation. 
Studies on the prevalence and spread of cohabitation in Finland). Oikeuspoliittisen tutkimuslaitoksen julkaisuja 49, 1981, 213 pp.

Hulkko, Jouko. Europe and the European Family in the Turn of the Century. Publications of the Population Research Institute Series D. N:o 8, 1982. The Population Research Institute Helsinki, Vammala 1982, 57 pp.

Marin, Marjatta \& Stolte-Heiskanen, Veroni$c a$. Suomalainen perhe, eristyy, yksityistyy, yhteiskunnallistuu. (The Family in Finland. The privatization of the family on the one hand and the growing socialization (bureaucratization) of traditional family functions). Tiede $2000-$ Science 2000, 2/1981, 5-10 pp.

Lastensuojelun keskusliitto. Miten lapsiperheillä menee? Lapsiperheiden rakennemuutokset, taloudellinen asema ja julkinen tuki. (How are families with children faring? The structural changes, economic position and public support of families with children). Helsinki 1982, 44 pp.

\section{H. MIGRATION}

\section{International Migration}

Borgegård, Lars-Erik \& Häggström, Nils. Migration decisions in theory and practise: Finland to Sweden after 1945. Policies of population redistribution, Geographical Society of Northern Finland for the IGU Commission on Population Geography, Oulu 1981, 125$140 \mathrm{pp}$.

Broberg, Richard. Suomalainen muuttoliike Ruotsin keskiosiin keskiajalta 1600-luvun loppuun. (Finnish migration to the middle parts of Sweden from the Middle Ages to the end of the 16 th century). Suomen kieli Ruotsissa - Finska sprảket i Sverige-sarja. Norden-Yhdistys ja Suomalais-Ruotsalainen Kulttuurirahasto, Tukholma 1980-1.

Koivukangas, Olavi. Australian siirtolaisuuden tutkimus. (Scandinavian Emigration to Australia: A Research Project). Siirtolaisuus Migration 1981: 2, 24-30 pp.

Lindström-Best, Varpu. The Impact of Canadian Immigration Policy on Finnish Immigration, 1890-1978. Siirtolaisuus - Migration 1981: 2, 5-15 pp.

Majava, Altti. Migrants: A Global Review. Siirtolaisuus - Migration 2: 1981, 16-23 pp. Majava, Altti. SOPEMI. Migrations from and to Finland 1979. Ministry of labor, Helsinki 1980, 50 pp.
Majava, Altti. Ruotsiin muuton näkymät 1980-luvulla. (The outlook for emigration to Sweden in the 1980's). Suomen sanoma 2: 1981, Siirtolaislehti, $28-30 \mathrm{pp}$.

Munter, Arja. Suomenruotsalaiset ja muuttoliike. (Swedish-speaking Finns and migration). Siirtolaisuus - Migration 1981: 3, 13-18 pp.

Nygård, Toivo. Etelä-Pohjanmaan Järviseudun siirtolaisuus - taloudellisten vaikuttimien kautta joukkoliikkeen mukaiseen käyttäytymiseen. (Emigration from the Lake District of Southern Ostrobothnia). Siirtolaisuus - Migration 4: 1981, 9-20 pp.

Koivukangas, Olavi \& Söderling, Ismo. Scandinavian Immigration to Australia and New Zealand. An international Symposium at the Institute of Migration. (The project's second symposium was held in Turku on February 17-19, 1982, attended by both Nordic and Australian scholars). Siirtolaisuus - Migration 1: 1982, 19-25 pp.

Siirtolaisasiain neuvottelukunnan mietintö VII. Paluumuutto. (Return migration). Komiteanmietintö 1982: 14, 53 pp. + 1 appendix.

Betänkande avgivet av delegationen för emigrantärenden V. Kommittébetänkande 1982: 63, $125 \mathrm{pp}$.

Heikkinen, E. et al. Siirtolaisuus Suomesta Ruotsiin ja takaisin (Emigration from Finland to Sweden and back). Department of Sociology, University of Joensuu, Joensuu 1981, 84 pp.

Tirkkonen, Tuomo. Suomalaiset Ruotsissa. (Finns in Sweden). Sosiaalinen aikakauskirja 4: 1981, Helsinki 1981, 4-7 pp.

Tuomi-Nikula, Outi. Unohdettu siirtolaisryhmä - suomalaiset Saksan Liittotasavallassa. (Die vergessene Auswanderergruppe - Die Finnen in der Bundesrepublik Deutschland). Siirtolaisuus - Migration 3: 1981, 19-26 pp.

\section{Internal Migration}

Helsingin kaupungin tilastokeskus. 17. 3. 1981. Helsingin sisäinen muuttoliike 1979. (Internal migration in Helsinki in 1979). Helsingin kaupungin tilastokeskuksen tilastouutisia; 1981, 4, 4 pp.

Herva, Aslak. 20-24-vuotiaiden miesten läänien välinen muuttoliike v. 1970 ja 1972 . (Migration between provinces among 20-24-year-old men in 1970 and 1972). Aluetiede. Sarja A: 3, University of Tampere, Tampere 1981, $38 \mathrm{pp}$.

Hietala, Kari. Internal Migration and Techno- 
logical Development. Yearbook of Population Research in Finland, XIX. The Population Research Institute, Vammala 1981, 28-46 pp.

Kanta-Hämeen seutukaavaliitto. KantaHämeen muuttoliike 1979. (Migration in KantaHäme in 1979). Julkaisu II: 115, Hämeenlinna 1981, 10 pp. + appendices.

Kanta-Hämeen seutukaavaliitto. KantaHämeen muuttoliike 1980. (Migration in KantaHäme in 1980). Julkaisu II: 122, Hämeenlinna 1982, 10 pp. + appendices.

Korkiasaari, Jouni \& Lindström, Kai \& Söderling, Ismo. Suomen suurimpien kaupunkien lähtömuuttajat vuosina 1977-1978. (The outmigrant from the biggest cities in Finland in 1977-1978). Department of Sociology and Political Research, University of Turku, Sarja A: 4, 1981,116 pp. + appendices.

Kymenlaakson seutukaavaliitto. Kymenlaakson muuttoliike 1960- ja 1970-luvuilla: Syitä ja seurauksia. (Migration in Kymenlaakso in the 1960s and the 1970s: Causes and effects). Julkaisu B: 58, Kotka 1982, 3 pp. + appendices.

Paasi, Anssi \& Vartiainen, Perttu. Keskuksen ja ympäristön välinen muuttoliike: tapaustutkimus Joensuusta. (Migration between the center and the environs: a case study of Joensuu). Terra 1981: 2, 57-72 pp.

Summa, Hilkka. Kaupunkien sisäinen muuttoliike muuttotyypeittäin. (Internal migration in towns by migration type). Yhdyskuntasuunnittelun jatkokoulutuskeskus, 1982, Julkaisusarja B 40, $131 \mathrm{pp}$.

Syrjäkari, Esko. Oulun kaupunkiseudun muuttoliike: Syyt ja vaikutukset aluerakenteeseen. (Migration in the urban area of Oulu: Causes and effects on the regional structure). Pohjois-Pohjanmaan seutukaavaliitto, Oulu 1982, Julkaisu A: 50, 83 pp. + appendices.

Vainio, Juhani. Flyttningsrörelse och avfolkning i sydvästra Finlands skärgård (Korpo, Rimito och Merimasku 1950-1974). Migration and Desettlement in the Archipelago of SouthWestern Finland (Korpo, Rimito and Merimasku in 1950-1974). University of Turku, Publicationes Instituti Geographici Universitatis Turkuensis N:o 92, Turku 1981, 158 pp. (English summary)

\section{HISTORICAL DEMOGRAPHY}

Engman, Max. Kazanskaja och Viborgskaja - rumsliga mönster bland peterburgsfinländar- na 1869-1910. (Kazanskaja and Vyborskaya Spatial Pattern among Finns in St. Petersburg 1869-1910). När samhället förändras - Kun yhteiskunta muuttuu. Societas Historica Finlandiae, Historiallinen Arkisto 76, Helsinki 1981, $321-350$ pp. (English summary)

Pitkänen, Kari. Avioitumiskäyttäytymisen muutokset teollistuvassa Suomessa. (Changes in nuptiality during the period of industrialization in Finland (ca. 1880-1950) När samhället förändras - Kun yhteiskunta muuttuu. Societas Historica Finlandiae, Historiallinen Arkisto 76, Helsinki 1981, 275-301 pp. (English summary)

Pohjois-Karjalan Historiallinen Yhdistys. ItäSuomen asutus- ja väestöhistoriaa. Itä-Suomen asutus- ja väestöhistoriallisen seminaarin esitelmät, Joensuu 27-28. 6. 1978. (Settlement and population history of Eastern Finland. Papers presented at the seminar on the settlement and population history of Eastern Finland, in Joensuu, June 27-28, 1978). Joensuu 1980, 82 pp.

Turpeinen, Oiva. Mortalitetskrisen i Finland åren 1788-1791. (Mortality crises in Finland in 1788-1791). Historisk tidskrift för Finland 1981: 1, 14-34 pp.

Virtanen, Keijo. The Use of Oral Testimony in Historical Demography. Yearbook of Population Research Institute, Vammala 1981, 87$95 \mathrm{pp}$.

\section{J. CHARACTERISTICS}

The City of Helsinki, Statistical Office. Living conditions in Helsinki 1950-1979. Helsinki 1981, 125 pp.

Haavisto, Matti \& Mattila, Kari. Tampereen vanhimmat asukkaat - tutkimus yli 85-vuotiaiden elinoloista ja terveydestä. (The oldest inhabitants in Tampere - a study of living conditions and health of over 85-year-old people). Tilastollisia tiedonantoja Tampereelta 1982: 1, Tampere 1982, 21-33 pp.

Jaakkola, Magdalena. Street Corner Finns in Sweden. Research Group for Comparative Sociology, University of Helsinki, Research Reports No. 29, 1981. Reprint from International J. of the Sociology of Law 1981, 9, 269-278 pp.

Koskenvuo, Markku. Mistä johtuvat sosiaaliryhmien väliset erot sydän- ja verisuonitautien esiintymisessä? Tutkimus ja kansanterveys 1980, Symposiumiraportti Osa II: Sydän- ja verisuoni- 
tautitutkimus. (Why are these differences in the prevalence of cardiovascular diseases between different social groups? Symposium on public health research 1980, Part II Cardiovascular research and nutritional research). Suomen Akatemian julkaisuja 4/1981, (The Academy of Finland) Helsinki 1981, 54-65 pp. (English summary)

Lundqvist, Bo \& Pellinen, Mikko. Väestönkehitys ja eläkeläistyminen lähivuosikymmeninä. (Population development and aging in the coming decades). Työeläke 1981: 5, 20-26 pp.

Ministry of Social Affairs and Health. Aging in Finland. Finnish national report for the world assembly on aging. Helsinki 1982, $77 \mathrm{pp}$.

Purola, Tapani. Väestön terveydentilaa säätelevien tekijöiden rakenne ja analyysi - Sosiaaliset tekijät. Tutkimus ja kansanterveys 1980, Symposiumiraportti Osa I: Yleisluennot. (The structure of the factors which regulate the population's state of health and the analysis of this structure. Symposium on public health research Part I: Lectures of a General Nature). Suomen Akatemian julkaisuja 3/1981, (The Academy of Finland) Helsinki $1981,66-80$ pp. (English summary)

Valkonen, Tapani. Vanhusten määrän kehitys. Vanhus-lähimmäinen, juhlajulkaisu, kunniapuheenjohtaja Martta Salmela-Järvisen 90vuotispäivän (31. 3. 1982) ja puheenjohtaja Elisabet Järvisen 70-vuotispäivän (17. 3. 1982) sekä heidän suorittamansa arvokkaan vanhustenhuoltotyön kunniaksi. (The development in the number of the elderly. The elderly - one's neighbor, an anniversary publication in honor of the 90 th birthday of honorary chairperson Martta Salmela-Järvinen and the 70th birthday of chairperson Elisabet Järvinen (March 17, 1982) and in honor of their valuable work in the care of the elderly). Vanhus ja Lähimmäispalvelun Liitto ry:n julkaisu no. 1, 64-73 pp.

Valkonen, Tapani. Väestön vanhenemisen demografisia näkökohtia. Osa I. Vanheneminen ja vanhusten huolto, Yrjö Jahnssonin säätiön lääketieteellinen symposiumi Hyvinkäällä 20.22. 8.1980. (Demographic viewpoints on the aging of population. Part I, Aging and care of the elderly. The medical symposium organized by the Yrjö Jahnsson Foundation in Hyvinkää in 20-22. 8. 1980.) Kansaneläkelaitoksen julkaisuja A: 16, Helsinki $1981,13-26$ pp.

\section{K. DEMOGRAPHIC AND ECONOMIC INTERRELATIONS}

Lankinen, Markku. Havaintoja Helsingin väestörakenteen ja tulotason kehityksestä - Observationer om utvecklingen av befolkningsstrukturen och inkomstnivån i Helsingfors. (Observations on Helsinki's Demographic Structure and Income Level). Neljännesvuosikatsaus 1981: 3, (Quarterly review 1981: 3) TILK, Helsingin kaupunki, 19-28 pp. (English summary)

\section{OTHER INTERRELATIONS}

Auvinen, Riitta. Asuminen ja syntyvyys. (Housing and fertility). Kanava 2: 1982, 77$80 \mathrm{pp}$.

De Geer, Eric. Migration and the Language Border. Yearbook of Population Research in Finland, XIX. The Population Research Institute, Vammala 1981, 61-86 pp.

Kaisla, Seppo. Asuminen ja elämänvaiheet. (Housing and phase of life). Väestöliiton julkaisuja - (Publications of the Finnish Population and Family Welfare Federation), Helsinki 1981, $256 \mathrm{pp}$.

Laakkonen, Risto. Suomalaiset Ruotsin työmarkkinoilla. (Finns in the Swedish labor market). Sosiaalinen aikakauskirja 4/1981, Helsinki 1981, 8-12 pp.

Naukkarinen, Arvo. Effects of communeinternal migration in Finland on the spatial distribution of population and on dwelling house utilization. Geographical Society of Finland, Fennia 159: 1, 1981, Helsinki 1981, 165-171 pp.

Paasi, Antti. Spatiaaliset preferenssit ja muuttaminen: Maantieteellinen näkökulma. (Spatial Preferences and migration - A geographical viewpoint). Siirtolaisuus - Migration 1981: 3, 2-12 pp.

Roos, J. P. Suomalainen murhenäytelmä: maaltamuuttaja-asuntosäästäjän tarina. Tutkimus yhteiskuntapolitiikan viitoittajana. Professori Leo Paukkuselle omistettu juhlakirja. (A Finnish tragedy: the story of a rural-to-urban migrant and persons saving up to buy a home. Research as a guide post for social development policy. An anniversary publication dedicated to Professor Leo Paukkunen). Jyväskylä Studies in Education, psychology and social research 42 . University of Jyväskylä 1981, 163-169 pp.

Rosenberg, Tomas. " Vi har en moralisk rätt till ett land»: pressdebatten om finlandssvenska 
framtidsstrategier sommaren 1980. ("We have a moral right to a native country.» Debate in the press in summer 1980 on the furure strategies of Swedish-speaking Finns). Språkgrupp och mobilitet. Forskningsrapporter. Ảbo Akademi Swedish University of Turku 1981, 109 pp. + pictures

Sandlund, Tom. Geografisk förändring bland en åldersgrupp finlands-svenskar 1950-1970. (Geographical change among an age group of Swedish-speaking Finns in 1950-1970). Ảbo Akademi-Swedish University of Turku 1981, Särtryck: Meddelanden från Stiftelsens för Ảbo Akademi forskningsinstitut, No. 60, 55-75 pp.

Sandlund, Tom \& Finnäs, Fjalar. Mobilitetsprojektets bakgrund och databas: delresultat. (Background and data base of the mobility project: partial results). Sprákgrupp och mobilitet. Forskningsrapporter 6. Åbo Akademi-Swedish University of Turku 1981, $114 \mathrm{pp}$.

Söderling, Ismo. The Main Characteristics of Migrants. Yearbook of Population Research in Finland, XIX. The Population Research Institute, Vammala 1981, 47-60 pp.

Turun yliopiston historian laitos. Muuttoliikkeiden ja sosiaalisen kehityksen väliset yhteydet. Suomen teollistumisen alusta maan itsenäistymiseen. (Relations between migration and social development. From the beginning of industrialization to Finland's independence). Department of History, University of Turku, Suomen Akatemian tutkimusprojektin 29 loppuraportti I, Turku 1982, $101 \mathrm{pp}$.

\section{POLICIES}

Lallukka, Seppo. Väestöpolitiikkaa tehostetaan Neuvostoliitossa. (Population policy is emphasized in the Soviet Union). Sosiaalinen aikakauskirja 1982: 5, 52-56 pp.

Suviranta, Annikki \& Säntti, Riitta. Day Care Subsidy for the Child at Home. A Finnish Experiment. Yearbook of Population Research in Finland, XIX, Vammala 1981, 96-103 pp.

Valtion tilintarkastuskertomus vuodelta 1980. Siirtolaisuus ja sen säătelymahdollisuudet. (Migration and the possibilities for its regulation). Työvoimaministeriön hallinnonala. Helsinki 1982, 245-248 pp. Siirtolaisuus - Migration 2: 1982, 34-38 pp.

Webb, John W. \& Naukkarinen, Arvo \& Kosiniski, Leszek A. Policies of Population redistribution. Geographical Society of Northern Fin- land for the IGU Commission on Population Geography, Oulu 1981, 201 pp.

\section{N. METHODS OF RESEARCH AND ANALYSIS}

Pöntinen, Seppo. Models and Social Mobility Research: A Comparison of Some Log-Linear Models for a Social Mobility Matrix. Department of Sociology, University of Helsinki, Working papers 16, 1981, $22 \mathrm{pp}$.

Rannikko, Pertti. Muuttoliiketutkimuksen lähestymistavoista. (Methods of approach in migration research). Sosiologia, Journal of the Westmarck Society, Vol. 18. N:o 2, 1981, $157-158 \mathrm{pp}$.

\section{O. ORGANIZATION AND ADMINISTRATION}

Hatunen, Hellevi. Elämisen uudet arvot, Haasteita 80-luvun perhepolitiikalle. (New life values. Challenges for family policy in the 80 's). Väestöliiton julkaisuja (Publications of The Finnish Population and Family Welfare Federation), Kolmikanta sarja 9, Helsinki 1981, 143 pp.

Heikkilä, Matti. Hallituksen perhepoliittisen selonteon eduskuntavastaanotto 25.-27.3. 1980. (Parliamentary reaction to the Government's report on family policy March 25-27, 1980). Sosiaali- ja terveysministeriö, Helsinki 1981,139 pp. + 2 appendices.

Korkiasaari, Jouni. Vuosina 1977-1978 maassamuuttaneet työvoimapoliittisesta näkökulmasta tarkasteltuna. (A labor market policy viewpoint on migration in Finland). Työvoimaministeriö, Työvoimapoliittisia tutkimuksia no. 27, lokakuu 1981, 141 pp.

Taloustieteen laitoksen julkaisuja 51/1982. Opintotuki perhekustannusten tasaajana. (Student financial aid as an equalizer of family expenditures). University of Jyväskylä, 117 pp. + 1 appendix

Rauhala, Urho. Mikä on järkevän perhepolitiikan esteenä? Sosiaalipolitiikka, historiallinen kehitys ja yhteiskunnan muutos. Juhlakirja Heikki Wariksen tăyttäessä 80 vuotta 25. 10 . 1981. (What is preventing a rational family policy? Social policy, historical development and social change. A book in celebration of Heikki Waris' 80 th birthday October 25,1981 ). Toim. Jaakkola, Risto \& Karisto, Antti \& Roos, J. P., Espoo 1981, 254-267 pp. 
Rissanen, Reino. Perhekustannusten tasaus ennakoivan lastensuojelun kivijalkako? (Equalizing family expenditures - the foundation of anticipatory child protection?) Lapset ja yhteiskunta 6-7: 1982, 391-393 pp.

Säntti, Riitta. Lasten kotihoidon tuen kokeilu vuosina 1978-1980. (An experiment with children's home care allowance from 1978-1980). Official Statistics of Finland, Research Department, Ministry of Social Affairs and Health, Special social studies XXXII: 81, Helsinki 1982, $115 \mathrm{pp}$.

Säntti, Riitta. Lasten kotihoidon tuen kokeilu vuonna 1979. Tutkimustiivistelmiä vuonna 1981. (An experiment with children's home care allowance 1979. Summaries of surveys in 1981). Official Statistics of Finland, Research Department, Ministry of Social Affairs and Health, Special social studies XXXII: 85, Helsinki 1982, 168-174 pp.

Säntti, Riitta. Lasten kotihoidon tuki huhtikuussa 1981. (Children's home care allowance in April 1981). Official Statistics of Finland, Research Department, Ministry of Social Affairs and Health, Special social studies XXXII: 85, Publications 10/1981, Summaries of Surveys in 1981, Helsinki 1982, 175-182 pp.

Säntti, Riitta. Lasten kotihoidon tuki huhtikuussa 1981. (Children's home care allowance in April 1981). Ministry of Social Affairs and Health, Publications 1981: 10, 59 pp.

\section{P. PROFESSIONAL MEETINGS AND CONFERENCES}

Haavio-Mannila, Elina. Vertailevan perhetutkimuksen kohteista ja kokemuksista. III suomalais-neuvostoliittolainen sosiologian symposiumi, Turku 21.-23. 10. 1980. (Focus and experiences in comparative family research). The III Finnish-Soviet symposium of sociology, Turku, October, 21-23, 1980). Helsinki 1981, $11-28 \mathrm{pp}$.

Koivukangas, Olavi \& Lindström, Kai \& Narjus, Raimo. Muuttoliikesymposium 1980, Turku 19.-21. 11. 1981. Esitelmät ja keskustelut. (Migration symposium 1980, Turku, November 19-21, 1981. Papers and discussions). Siirtolaisuusinstituutti, Siirtolaisuustutkimuksia A 8, Turku 1982, 402 pp.

Multietniska samordningskommitten (MEKS). Multietniska symposier i Åbo vid migrationinstitutet, Ảbo Akademi och Turun yliopisto den
10-12 september 1981. (Multiethnic symposiums in Turku at the Migration Institute, the Swedish University of Turku and the University of Turku on September 10-12, 1981). Humanistiska fakulteten. Uppsala universitet.

Rannik, E. E. \& Kelam, A. A. Vertailevan tutkimusten toteuttamisesta perhesosiologian alalla (Eestin ja Suomen aineistojen pohjalla). III suomalais-neuvostoliittolainen sosiologian symposiumi. Turku 21.-23.10.1980. (Carrying out comparative research in family sociology [on the basis of Estonian and Finnish material]. The III Finnish-Soviet symposium of sociology). Helsinki 1981, 29-33 pp.

Perheentupa, Olli. III suomalais-neuvostoliittolainen sosiologian symposiumi. Turku 21.23. 10. 1980. Suomen ja Neuvostoliiton välisen tieteellisteknillisen yhteistoimintakomitean julkaisusarja. (The III Finnish-Soviet symposium of sociology. Turku 21.-23. 10. 1980. Publications of the Finnish-Soviet Committee on Scientific-Technological Cooperation). Helsinki $1981,155 \mathrm{pp}$.

\section{Q. BIBLIOGRAPHIES}

Bibliography of Finnish Population Research 1979-1980. Yearbook of Population. Research in Finland, XIX, The Population Research Institute, Vammala 1981, 106-118 pp.

Bibliography of Finnish Demography, 19451978, Preliminary edition. The Finnish Demographic Society, Helsinki 1980, 261 pp.

\section{R. OFFICIAL STATISTICAL PUBLICATIONS}

Avoliitossa elävät 1981. (Cohabitation in 1981). Central Statistical Office of Finland, Statistical reports VÄ 1982: 7, Population, 5 pp.

Espoon väestölaskelma 1982-1987. . (Population projection in Espoo 1982-1987. .) Espoon kaupungin toiminta- ja taloussuunnitteluosasto, tilastotoimisto, Espoo 1982, 132 pp.

Helsinki district by district. The City of Helsinki, Statistical Office, Helsinki 1982, 381 pp. + app.

Helsingin văestö 1. 1. 1980. (Population of Helsinki 1. 1. 1980). The City of Helsinki, Statistical Office, Tilastoja 1981 A: 1, Helsinki 1981, 77 pp. + app.

Helsingin väestö 1. 1. 1981. (Population of Helsinki 1. 1. 1981). The City of Helsinki, Sta- 
tistical Office, Tilastoja 1981 A: 3, Helsinki 1981, 81 pp.

Turun henkikirjoitettu väestö 1. 1. 1982. (The population of Turku according to domicile registers 1. 1. 1982). Turun kaupungin tilastotoimiston tiedotuksia 1982: 5, 20. 8. 1982.

Henkikirjoitettu väestö kunnittain 1. 1. 1981. (Population according to domicile registers by municipalities 1. 1. 1981). Central Statistical Office of Finland, Statistical reports VÄ 1981: 6, Population, $52 \mathrm{pp}$.

Henkikirjoitettu väestö kunnittain 1. 1. 1982. (Population according to domicile registers by municipalities 1. 1. 1982) Central Statistical Office of Finland, Statistical reports VÄ 1982: 9, Population, $14 \mathrm{pp}$.

Ikä ja ammattitilastot 1979. (Age and occupation statistics 1979). Kansaneläkelaitoksen tilastollisia vuosikatsauksia, Helsinki 1981, 135 pp.

Life tables 1976-80, Central Statistical Office of Finland, Statistical reports VÄ 1982: 6 Population, $8 \mathrm{pp}$.

Life tables 1979. Central Statistical Office of Finland, Statistical reports VÄ 1982: 2, Population, 9 pp.

Life tables 1980. Central Statistical Office of Finland, Statistical reports VÄ 1982: 1, Population, 12 pp.

Kunnittainen väestöennuste 1981-2000. (Population Projection by Municipalities 19812000). Central Statistical Office of Finland, Statistical reports VÄ 1982: 5, Population, 93 pp.

Perheet 1980. (Families 1980). Central Statistical Office of Finland, Statistical reports VÄ 1982: 4, Population, $66 \mathrm{pp}$.

Perheet alueittain Helsingissä 31. 12. 1979. (Families in Helsinki by district 31. 12. 1979). The City in Helsinki, Statistical Office, Tilastoja 1981 A: 2, Helsinki 1981, 78 pp.

Population 1979. Volume I: Structure of Population and Vital Statistics Whole Country and provinces. Central Statistical Office of Finland, SVT VI A: 144, Helsinki 1981, 89 pp.

Population 1979. Volume II: Structure of Population and Vital Statistics by Commune. Central Statistical Office of Finland, SVT VI A: 144, Helsinki 1981, 148 pp.

Population 1979. Volume III: Internal migration by Commune. Central Statistical Office of Finland, SVT VI A: 144, Helsinki 1981, 163 pp.

Population 1980. Volume I: Structure of Population and Vital Statistics Whole country and provinces. Central Statistical Office of Finland, SVT VI A: 145, Helsinki 1982, 105 pp.

Population 1980. Volume II: Structure of Population by Communes. Central Statistical Office of Finland, SVT VI A: 145, 79 pp.

Population 1980. Volume III: Vital Statistics by Commune. Central Statistical Office of Finland, SVT VI A: 145, Helsinki 1982, 172 pp.

Population and Housing Census 1980. Volume VII: Household-dwelling units and families. Central Statistical Office of Finland, SVT VI C: 106, Helsinki 1982, 407 pp.

Population and Housing Census 1980. Volume X: Building stock, business premises. Central Statistical Office of Finland, SVT VI C: 106, Helsinki 1982, 451 pp.

Population and Housing Census 1980. Volume XIX: Labour force survey. Central Statistical Office of Finland, SVT VI C: 106, Helsinki 1981, 60 pp. +4 appendices

Syntyvyys Turussa 1960-1980, syntyneiden määrä. (Fertility in Turku 1960-1980, the number of births). Turun kaupungin tilastotoimiston tiedotuksia 1982: 3, 24. 5. 1982, 18 pp.

Väestö- ja asuntolaskenta Helsingissä vuonna 1980: käyttöönsaattamisen suunnitelma. (Population and Housing census in Helsinki 1980. Plan for application of the census 20.10. 1981). The City of Helsinki, Statistical Office, Muistioita 1981: 7, $113 \mathrm{pp}$.

Alueittaiset vãestönmuutokset Helsingissä 1979. (Regional vital statistics in Helsinki 1979). The City of Helsinki, Statistical Office, Tilastouutisia 1981, 25. 11. 1981, $12 \mathrm{pp}$.

Väestönmuutokset 1980. IV. neljännes ja koko vuosi sekä väkiluku 31. 12.1980. Koko maa, läänit, seutukaava-alueet ja kunnat. (Vital Statistics 1980. VI quarter, I-IV quarter and population 31. 12. 1980 by provinces, regional planning areas and municipalities). Central Statistical Office of Finland, Preliminary data, Statistical reports VÄ 1981: 3, Population, 52 pp.

Väestönmuutos ja väestönrakennekertoimet lääneittäin, seutukaava-alueittain ja kunnittain 1979. (Vital statistics and population structure and rates by provinces, regional planning areas and municipalities 1979). Central Statistical Office of Finland, Preliminary data, Statistical reports VÄ 1981: 4, Population, 49 pp.

Väestönmuutokset 1981. IV. neljännes ja koko vuosi sekä väkiluku 31. 12. 1981. Koko maa, läänit, seutukaava-alueet ja kunnat. (Vital statis- 
tics 1981. IV quarter and population 31. 12. 1981 by provinces and regional planning areas and municipalities). Central Statistical Office of Finland, Preliminary data, Statistical reports V Ä 1982: 3, Population, $52 \mathrm{pp}$.

Väestönmuutokset 1982. II neljännes sekä väkiluku 30. 6. 1982. Koko maa, läänit, seutukaava-alueet ja kunnat. (Vital statistics 1982. II quarter and population 30.6. 1982 by provinces, regional planning areas and municipalities). Central Statistical Office of Finland, Preliminary data, Statistical reports VÄ 1982: 10, Population $33 \mathrm{pp}$.

Väestönmuutokset ja perheet 1980. (Vital statistics and families 1980). Perustilastoja Espoosta 27. Toiminta- ja taloussuunnitteluosasto, tilastotoimisto, Espoo 1982, 69 pp.

\section{AUTHOR INDEX}

\author{
Aho, Harri - B \\ Aromaa, Kauko - G \\ Asp, Erkki - B \\ Auvinen, Riitta - L \\ Borgegåra, Lars-Erik - $\mathrm{H}_{1}$ \\ Boström, Harry (toim.) - E \\ Broberg, Richard $-\mathrm{H}_{1}$ \\ Cantell, Ilkka - G \\ Engman, Max - I \\ Finnäs, Fjalar — L \\ Fougstedt, Gunnar - D \\ De Geer, Eric — L \\ Haavio-Mannila, Elina - P \\ Haavisto, Matti - J \\ Hatunen, Hellevi (toim.) - O \\ Heikkilä, Matti (toim.) - O \\ Heikkinen, E. et al. $-\mathrm{H}_{1}$ \\ Herva, Aslak $-\mathrm{H}_{2}$ \\ Hietala, Kari $-\mathrm{H}_{2}$ \\ Hulkko, Jouko - G - \\ Häggström, Nils $-\mathrm{H}_{1}$
}

Jaakkola, Magdaleena - J

Jaakkola, Risto - G
Kaisla, Seppo - L

Kelam, A. A. - P

Kettunen, Paavo - E

Kirkinen, Heikki (toim.) - B

Koivukangas, Olavi $-\mathrm{H}_{1}, \mathrm{P}$

Korkiasaari, Jouni - $\mathrm{H}_{2}$, O

Kosiński, Leszek, A. (toim.) - M

Koskenvuo, Markku - J

Kuusilinna, Pirjo - B

Laakkonen, Risto - L

Lallukka, Seppo - A, M

Lankinen, Markku - K

Lindgren, Jarl — D

Lindgren, Susanne - F

Lindström-Best, Varpu $-\mathrm{H}_{1}$

Lindström, Kai - $\mathrm{H}_{2} \mathrm{P}$

Lithell, Ulla-Britt - F

Ljungstedt, Nils - E

Lundqvist, Bo - J

Majava, Altti $-\mathrm{H}_{1}$

Marin, Marjatta - G

Martelin, Tuija - E

Mattila, Kari - J

Melkas, Jussi - B

Munter, Arja - $\mathrm{H}_{1}$

Myhrman, Antero - F

Mäenpää, Toivo - B

Narjus, Raimo - $\mathrm{P}$

Naukkarinen, Arvo - M, L

Niemi, Marja-Liisa - E

Notkola, Veijo - E

Nurmela, Juha - B

Nygård, Toivo $-\mathrm{H}_{1}$

Oulasvirta, Lasse $-\mathrm{H}_{2}$

Paasi, Anssi - $\mathrm{H}_{2} \mathrm{~L}$

Pellinen, Mikko - J

Peltonen, Raili - F

Perheentupa, Olli (toim.) - P

Pitkänen, Kari — I

Purola, Tapani - J

Pyörälä, Kalevi - E

Pöntinen, Seppo - N

Rannik, E. E. - P

Rannikko, Pertti - N

Rasmussen, Johnny - D

Rauhala, Urho - O

Rinne, Seppo - B 
Rissanen, Reino - $\mathrm{O}$

Ritamies, Marketta - D

Roos, J. P. - L

Rosenberg, Thomas - L

Saari, Matti $-\mathrm{H}_{2}$

Salo, Mikko a. - F

Sandlund, Tom - L

Sauli, Hannele - E

Stolte-Heiskanen, Veronica - G

Summa, Hilkka $-\mathrm{H}_{2}$

Suviranta, Annikki - M

Syrjäkari, Esko - $\mathrm{H}_{2}$

Säntti, Riitta - M, O

Söderling, Ismo $-\mathrm{H} 1, \mathrm{H}_{2}$, L

Tirkkonen, Tuomo $-\mathrm{H}_{1}$

Tuomi-Nikula, Outi $-\mathrm{H}_{1}$

Turpeinen, Oiva - I

Vainio, Juhani $-\mathrm{H}_{2}$

Vakkamaa, Juhani - B

Valkonen, Tapani - D, E, J

Vanamo, Jorma - A

Vartiainen, Perttu $-\mathrm{H}_{2}$

Webb, John. W. - M

Virtanen, Keijo I 